\title{
THE HISTORY OF THE CHILDHOOD \\ IN THE EARLY MODERNISM'S PERIOD: \\ REVIEW OF THE EUROPEAN \\ AND UKRAINIAN HISTORIOGRAPHY
}

Serdiuk I. O.

\section{INTRODUCTION}

The contemporary society is becoming even more child-orientated. Meanwhile the childhood is vigorously leaving its established frameworks: family, study, a respective branch, and is globalizing, significantly influencing politics or becoming natural in international movements. Greta Thunberg is a bright example of this process, whose activity is highly evaluated (from condemnation to admiration) but nevertheless it's impossible not to be noticeable. Probably this model is the brilliant embodiment of a gradually disappearing modernism childhood model formed in the XIXth century. On the other hand plenty of participants of the enhanced modern teenager movements discussions are extremely fond of the historical parallels research which has much in common with the so-called "childish crusade". Such comparisons do not take into account the difference between current and premodernism societies particularly in understanding children's things, the essence and nature of childhood. Such important components of culture as for example the value of children's matters, family strategies, parental feelings are drastically changing during the couple of decades. Instead, these models are supposed to have been strictly represented in the past as fixed, unchangeable, "immortal". Even more in modern Ukraine this alleged "immortality" of recognizing family and childhood is used even as the object of political manipulations. The matter is in the usage of fixed stereotypes about allegedly "ideal Ukrainian old times" to which we should return.

It's very important to recognize that such stereotypes were formed by the ignorance of historical context and the false understanding of the heritage of the $19^{\text {th }}$ century literature. Thus the most stable "childish" images in Ukrainian educational literature or science-fiction historical literature are an orphan boy who's accompanied by Kobzar, a jura, an underage mercenary, a shepherd. Such figures are similar to each other, they are often tragic but their own charm is hidden in other positive examples of large families, mutual efforts from parents and numerous children in family business etc. The total anonymity of "girl's attributes" and the absence of the proper vivid girls' characters are the evidence of one-sided similar understanding. The 
patriarchal culture is absolutely not decoded with a reference to childhood. Afterall the Ukrainian childhood in pre-modernism era hasn't been researched yet properly and what is more even the exploring of something "childish" sometimes could be very extravagant for Ukrainian historiography but that can't be said about the situation in Europe where it has been exploring actively for several decades. In this sense I try to determine the reasons of such a gap. So I am going to use the description of Western children orientated practices' development and the history of childhood in early modernism period based on European examples simultaneously paying attention to the main legacy of Ukrainian historians. Respectively you can find the attempt of generalizing the problem and prospects of historiography of early modernism's childhood in Ukraine.

\section{The history of childhood before Philippe Ariès}

Nowadays the role of children-orientated practices in modern global historiography is beyond any doubt. The practical elaboration of the topic is noticeable even institutionally - especially within professional scientific journals such as "Journal of the History of Childhood and Youth"1 However this phenomenon isn't new. Twenty years ago Hugo Cunningham, a prolific British researcher, wrote in a special historiography review that the history of childhood is blooming. He explained the increasing demand for such practices. From the end of the $20^{\text {th }}$ century "Western world" has been worrying about children, their nurture, reconsideration of their rights and duties. Commercialization of children's things and the whole industry is added to all aspects and that influences the society in its own way. It has often been resorted to historical researches while trying to explain these new phenomena. Scholars also promptly reacted on society's demands to understand better the nature of a child. From historians people just started to expect the explanation of the historical origin of current problems relating to childhood and adulthood, conflicts between generations. The exploration of the reasons of childhood's differentiation has become another direction of the observation because besides social well-being countries there are countries where children suffer from starvation, where pandemic is the cause of massive loss of children's life and where children don't get proper care and education ${ }^{2}$.

From my point of view Hugo Cunningham has explained the development of childhood's history with a child-orientated modern society that is with "external" incentives but not with internal scientific demands. Instead of this a

\footnotetext{
${ }^{1}$ https://www.press.jhu.edu/journals/journal-history-childhood-and-youth

${ }^{2}$ Cunningham H. Histories of Childhood. The American Historical Review. 1998. Vol. 103. Issue 4. P. 1195-1196.
} 
well-known British historian Peter Burke explained the popularity of such themes with cultural relativism which make impossible division of historical field into "central" and "peripheral". In other words Burke meant the negation of unimportant and uninteresting themes. This relativism (according to the scholar) was a significant peculiarity of "The New History" with its total nature and interdisciplinary approach ${ }^{3}$. The examples of the interest of "The New History" given by Burke are in some ways similar to the famous on the post-Soviet territory prolific medieval Aron Gurevich's list. This similarity is interesting for us due to the role of childhood in both cases. The reasons of a resurgence of interest to the early not interesting topics according to the Soviet scholar among other things are hidden in overcoming limits which separate a profession of historian from other humanities relating to human: ethnology, sociology, psychology, demography, linguistics, etc. ${ }^{4}$

Both Burke and Gurevich meant the anthropological change in humanities and their consequences, they both discovered new spheres of study researching issues in a new way, in a study of seemingly conventional issues. 1960 became a symbolic boundary for history of childhood in this context. It was exactly the time when the work "Centuries of Childhood. A Social History of Family Life" (L'enfant et la vie familiale sous l'Ancien régime) by Philippe Ariès was published $^{5}$. This book is a starting point for a modern historian of childhood in spite of whether he accepts Ariès' theses or denies them. The researchers of French scholar were like an intellectual provocation that induced the interest to the study of the topic and created a natural stir for such researches. At first sight it even seems that history of childhood before Ariès didn't exist.

In fact a child didn't belong directly to a sphere of interests of a wide range of historians. Clergymen, economists and sociologists are among the first who paid their attention to childhood. The impulse was the reducing of birth rate at the end of the $18^{\text {th }}$ century that on the one hand increased the significance of the child but on the other hand became a cause for discussions about reasons of such reduction and its appraisal (is it good or bad?). Such arguments obligatory dealt with the issues of poorness, social inequality, children's exploitation, delinquency, living from hand to mouth and so on ${ }^{6}$.

${ }^{3}$ Берк П. Вступ. Нова історія: їі минуле і майбутнє. Нові підходи до історіописання. Київ, 2010. С. 15-19.

${ }^{4}$ Гуревич А. Смерть как проблема исторической антропологии: о новом направлении в зарубежной историографии. Одиссей. 1989. С. 116-117.

5 Ariès P. L'enfant et la vie familiale sous l'Ancien régime. Paris, 1960. Англомовний переклад книжки звучить як “Століття дитинства": Centuries of Childhood. A Social History of Family Life. New York, 1962. В Україні поширена російська версія: Арьес Ф. Ребенок и семейная жизнь при старом порядке. Екатеринбург, 1999.

6 Любарт М. Историко-этнологическое изучение детства во французской науке (до и после Ф. Арьеса). “Вся история наполнена детством”: наследие Ф. Арьеса и новые подходы к истории детства: В 4 ч. Ч. 1. Москва, 2012. С. 128-129. 
Some theses turned into theories which had become out of date for example malthusianism which was founded by an English clergyman and economist Thomas Malthus. In his essay "On the Principle of Population" (1789) he argued that the population grows considerably faster than resources. According to Malthus that was the main cause of poorness. He was one of the first who appealed to limitations of birth rate with the help of self-control, entering into a marriage only if a person has financial ability to maintain children. These thoughts became the central idea of the study which was criticized by Soviet scholars in the past. And even now the materials about malthusianism are being sometimes written in an estimating mood (in most cases negative) in post-Soviet countries. At the same time it's necessary to take into account that Malthus' ideas were later significantly transformed but those were especially the issues relating to ecology, manufacturing efficiency ${ }^{7}$.

In the XIXth century the topic of childhood became interesting for European lawyers. It was the time of discussion of legislative initiatives relating to an underage individuals, especially the issues about the custodianship and safety and also the change of the the status of illegitimate children. It's very important that Ukrainian men of law of those times worked in a close collaboration with their European counterparts. Among them the most outstanding works belong to Oleksandr Bogdanovsky and Oleksandr Kistyakivskyi. These works contain numerous historical information and very useful facts. They were concerned not only about the delinquency (according to the title) but they also were focused on the approaches of discussion the age of children in context with the law in different countries. Thus they left their contribution in this sphere in large European annals ${ }^{8}$. For modern historians the unreleased legacy of Kistyakivskyi can also be attractive especially due to his manuscript notes "The principles of children and underage's behavior".

These researches made by economists, sociologists, lawyers draw a distinction not only between precedents, facts or theories. They put into use a specialized brand of new notions and concepts which were set to be used by researchers from other branches of humanities who represent the conventional-based society. Thus starting from the middle of the $19^{\text {th }}$ century ethnographers and ethnologists began taking children into consideration. The

\footnotetext{
${ }^{7}$ Malthus, Medicine \& Morality: "Malthusianism” After 1798. Amsterdam; Atlanta, 2000.

${ }^{8}$ Богдановский А. Развитие понятий о преступлении и наказании в русском праве до Петра Великого. Москва, 1857; Його ж. Молодые преступники: Вопрос уголовного права и уголовной политики. Санкт-Петербург, 1871; Кистяковский А. Молодые преступники и учреждения для их исправления, с обозрением русских учреждений. Киев, 1878.

9 Інститут рукопису Національної бібліотеки України імені Вернадського. Ф. 61. Спр. 127.
} 
circle of issues which were studied in this context was multi-purposed for scholars from different countries: children's ceremonies of birth and burial, rites and superstitious beliefs relating to pregnancy and caring for babies, conventional methods of early socialization, the work of children, materialistic culture of childhood, magic practices ${ }^{10}$. Ukrainian ethnography developed in the similar way first of all paying its attention to the birth of a child. Especially the focus was on birth practices ${ }^{11}$, ceremonies of birth giving $^{12}$, family budget ${ }^{13}$. Two large articles made by Petro Ivanov ${ }^{14}$ and Mykola Sumtsov ${ }^{15}$, prominent ethnographers and researchers from Slobozhanshchyna are distinguished among the other works. The last script was also notable for its bearing of foreign counterparts' work and professional analysis.

In general Ukrainian ethnography of childhood of that time evolved as

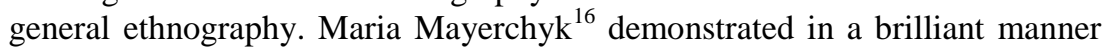
its evolution from amateur practices on the level of folk romantism to professional researches in the early $20^{\text {th }}$ century. She also paid her attention to how researchers had created a relevant scientific instrument for dealing with the object of the research. Therefore contemporary notions with imaginary archaism were built in corpus of traditional culture. In other words new components became ancient and versatile ${ }^{17}$. It's significant that Maria Mayerchyk observed this modernization of the archaic (or vice versa archaization of modern) on the example of the most valuable (till now)

10 Докладніше про розвиток етнографічних досліджень дитинства у другій половині XIX - на початку XX ст. див.: Любарт М. Историко-этнологическое изучение детства. С. 128-130; Кон И. Ребенок и общество: Историко-этнографическая перспектива. Москва, 1988. С. 12-39.

${ }_{11}^{11}$ Талько-Грынцевич Ю. Народное акушерство в Южной Руси. Чернигов, 1889.

12 Беньковскій И. Поверья и обрядности родын и крестын. Киевская старина. 1904. № 10. С. 1-3; Онищук А. 3 народнього життя гуцулів. І. Родини і хрестини та дитина до шестого року життя. Матеріяли до української етнольогії. Т. ХV. Львів, 1912. С. 90-113; Шекерик-Доників П. Родини і хрестини на Гуцульщині (В селі Головах і Красноілі Косівського пов.). Матеріяли до української етнольогї̈. Т. ХVIII. Львів, 1918. С. 36-122.

${ }^{13}$ Милорадович В. Житье-бытье лубенского крестьянина. Українці: народні вірування, повір'я, демонологія. Київ, 1992. С. 170-341.

${ }^{14}$ Иванов П. Этнографические материалы, собранные в Купянском уезде Харьковской губернии. Приметы и поверья, относящиеся к беременности и к рождению детей. Этнографическое обозрение. 1897. № 1. С. 22-70.

${ }^{15}$ Сумцов Н. О славянских народных воззрениях на новорожденного ребенка. Журнал Министерства народнаго просвещения. 1880. № 11. С. 69-94.

16 Маєрчик М. Ритуал і тіло. Структурно-семантичний аналіз українських обрядів родинного циклу. Київ, 2011. С. 20-37.

${ }^{17}$ Маерчик М. Анализ дискурсов в исследованиях украинской традиции добрачных ночевок молодежи (конец XIX - XXIв.). Антропологический форум. 2015. № 24. C. $110-115$. 
Ukrainian ethnographic research of childhood - "The role of a child in Ukrainian customs and beliefs". Marko Hrushevs'kyi, a clergyman from Kyiv county, was one of the creators of the research. He had rounded up materials about motherhood's and childhood's culture diligently including the direct speech straight from the horse's mouth. Thanks for his holy orders Hrushevs'kyi had gotten evidences which often had an intimate, private character and other researchers couldn't get them. Zenon Kuzela put all information in order and prepared it for publishing. The work was released in 1906-1907 and till today it remains a real encyclopedia of everything relating to childhood in conventional culture - from the conception of taking care for a child and his adulthood. In spite of facts, Kuzela's comments have a significant value. Thanks to them we can observe his erudition and comprehension of similar foreign works (first of all written in German). It was the result of his practices at the University of Vienna ${ }^{18}$. Despite the background of one of the compilers, this work has a prevailed descriptive character as well as the other precious research made by Nina Zaglada "The life of a country child". The plot of the book is based on is rigorous ethnographic observations made in the village of Starosillya. It was dedicated to the life of the children from the age of about 3 to 15. In particular the book is about the way of dressing, nutrition, leisure activities, work and an authentic views of a child ${ }^{19}$.

Although the above mentioned Ukrainian ethnographers' researches contained facts and necessary interpretations they didn't become a real ground for theoretical general conclusions of their French counterpart Arnold van Gennep. In the book "The Rites of Passage" he managed to put rituals in the right order and combined them into one structural system where the child is one to play an important role in the process of growing ${ }^{20}$. Nevertheless the works of an American researcher Margaret Mead are considered classical and the most prominent in the sense of theoretical understanding of ethnography of childhood because she was the first who had made childhood's world the main subject of research.

In a scientific bestseller "Coming of Age in Samoa", released in 1928, Mead showed how culture influences the socialization of a child. According to her interpretation childhood and youth are the phenomena which are viewed in different ways in various societies, though taking into account identical

18 Дитина в звичаях і віруваннях українського народу. Матеріали з полудневої Київщини. Зібрав Марко Грушевський. Обробив д-р Зенон Кузеля. Матеріали до украӥнсько-руської етнольогї. Т. VIII. Львів, 1906; Т. ІХ. Львів, 1907.

19 Заглада Н. Побут селянської дитини. Матеріали до монографії с. Старосілля. Київ, 1929.

${ }^{20}$ Геннеп ван А. Обряды перехода (систематическое изучение обрядов). Москва, 1999. 
biological premise ${ }^{21}$. Later the methods of data collecting and deductions of Margaret Mead were severly criticized by the anthropologist Derek Freeman who in 1983 published the book named "Margaret Mead and Samoa: The Making and Unmaking of an Anthropological Myth"22. However Mead's researches remain valuable today because the author considers childhood a marker of society's functioning and relies on her formation of three types of culture which have existed throughout all human history. I pay attention to one thing that Margaret Mead has founded-thanks to the results of her own research she explained the nature of problems of a modern society of her days in the nurture of children, relationships between parents and children, a generation gap. In this sense she made an opposition from coming of age in Samoa to American realities and a generation gap which in those times were called ideal. In general the works of this researcher might be considered as an apogee of such a stage when the study of childhood "in the past" was the monopoly of ethnologists. Unfortunately those methodological innovations weren't put into Ukrainian practice. In the first half of the $20^{\text {th }}$ century Ukrainian historiography has already been isolated from the Soviet scientific circle. Foreign ethnology was considered to be hostile and was a taboo. So in the first Russian translation of a selected Mead's work appeared in $1988^{23}$, there is no Ukrainian translation even till now. This fact speaks eloquently for understanding why Ukrainian historians begin to seriously observe childhood as one of the "keys" for comprehension society just at the end of the XXth century.

\section{Philippe Ariès and development of the history of childhood}

Margaret Mead's ethnological monopoly had lasted until 1960 when Philippe Ariès' the above mentioned work changed the situation. A French scholar's book broke down the interdisciplinary boundaries and led to the transformation of a child from nothing to scientific interests of professional historians. The bottom line of the research is childhood observed as a changeable social component. On the example of pre-modernism France Aries demonstrates that there are several patterns of childhood's perception in the same society and they are interchangeable. The research chronologically started from XII century when according to the thoughts of a French scholar a child wasn't distinguished from the adult world and was treated like a little adult or a dwarf who was going to grow. Ariès showed how through centuries a baby was losing his anonymity. Childhood was considered as a special stage

\footnotetext{
${ }^{21}$ Mead M. Coming of Age in Samoa: A Psychological Study of Primitive Youth for Western Civilization. New York, 1928.

${ }^{22}$ Freeman D. Margaret Mead and Samoa: The Making and Unmaking of an Anthropological Myth. Cambridge, 1983.

${ }^{23}$ Мид М. Культура и мир детства. Избранные произведения. Москва, 1988.
} 
of life (XVI century) but a child gradually moved from periphery of family's attention to its center. Later some Ariès' critics criticized him for the denial of childhood as the stage of life in pre-modernism society. However he hadn't affirmed it. To make a long story short Ariès meant youth to be the latest component and it was distinguished from the end of the XVIIIth century. In the same time a modern pattern of childhood was set to be established, the base of which was already formed in the $19^{\text {th }}$ century when mass education, specific social institutions, industrialization, changes in lawmaking, mass printing of specialized literature and the other things were put into lives of ordinary people. It's worth noticing that such fundamental components for the establishment of childhood as family, parent's love, the right treatment of a child weren't stable according to Ariès, they were constantly changing transforming the image of childhood. These alterations aren't thought to be the development or the unconditional welfare. Here the historians deal with the concept of discipline. Separating a child from their own world adults set numerous prohibitions, limitations, narrow definition of the right behavior. In such a way a child is restricted from a very young age and further it goes, less freedom the child has ${ }^{24}$.

With this hypothesis Ariès also explained the hardships of a child's socialization in France in the second half of the $20^{\text {th }}$ century. He found the causes of psychological disturbance and intergenerational discords in the restrictions of a child by adults, the child's upbringing in a small family and the establishment of a consumer's outlook. The scholar came in contact with psychologists and found common grounds within research interests. Psychologists of that time also positively evaluated his works evolving them thanks to the achievements of their study. The most successful from their circle is an American psychohistorian Lloyd DeMause who proposed his original conception of a child's evolution in the context of his study about psychohistory. The scholar presented a child's evolution as a modern movement of getting closer parents and children by finding out how parents knew their descendants. That movement had six conditional stages (patterns): infanticide (before the $4^{\text {th }}$ century), distant mode $\left(4^{\text {th }}-13^{\text {th }}\right.$ century), ambivalent mode $\left(14^{\text {th }}-17^{\text {th }}\right.$ century), imposition mode $\left(18^{\text {th }}\right.$ century), socialization mode $\left(19^{\text {th }}-\right.$ mid $20^{\text {th }}$ century). I am convinced that "The Evolution of Childhood" in the light of research demonstrated a certain significance in the sense of interdisciplinarity's problems. DeMause - a perfect pundit in the sphere of a child's psychology and psychoanalysis gave superb positive comments of the historical aspect of the work. At the same

\footnotetext{
${ }^{24}$ Арьес Ф. Ребенок и семейная жизнь.
} 
time he criticized categorically historians' job because they allegedly extremely embellished the childhood in the past ${ }^{25}$.

Returning to the personality of Ariès I should notice that the innovation of his work was also in a wide range of references: from literature, diaries and letters to epitaphs, gravestone bas-reliefs, iconography and pictures. The scholar raised the issues which weren't discussed at that time. His contribution was approved by fierce critics of Ariès although they didn't accept his conclusions. The book of the French scholar completely coped with the role of intellectual provocation causing ardent discussions and numerous studies of the history of childhood ${ }^{26}$. The most valuable works used Ariès' approaches and conclusions in other materials (spheres of science) hence emphasizing their importance.

It's interesting that even the weakest points of the French historian's work provoked constructive criticism which later transformed into complete directions of researches. Maybe the largest part of criticism Ariès had ever got for his works containing iconography, pictures and materialistic monuments, for he allegedly didn't pay attention to the proper selection of the items, i.e. he had chosen visual sources and artefacts in a chaotic order and did not apply a systematic approach. And then he described them in an exceedingly simplified way seeking something routine or "the imprint of the epoch" in canonical elements which passed through centuries without changes and hadn't any correlation with reality ${ }^{27}$.

\section{The history of childhood after Philippe Ariès}

After Ariès' era the researchers very carefully and with trepidation used visual sources and gave explanations of artefacts. With coming out of numerous works the interest towards the material world of a child was renewed at the end of 1980-s because the authors had given up direct descriptive methods and concentrated on a detailed analysis of artefacts ${ }^{28}$. Among other works Karin Calvert's book is extremely significant because

25 DeMause L. (1982). Foundations of psychohistory. New York, 1982; ДеМоз також упорядкував збірник наукових есеїв про дитину і насильство від Середньовіччя до XIX ст.: DeMause L. The History of Childhood: The Untold Story of Child Abuse. Northvale, New Jersey, 1995.

${ }^{26}$ Про тенденції в розвитку таких студій і бібліографію праць докладніше див. спеціальне теоретично-довідкове видання: Bowman V. Scholarly Resources for Children and Childhood Studies: A Research Guide and Annotated Bibliography. Toronto, 2007. Більш стисло і предметно див.: Безрогов В., Кошелева О. Детство и дети: начальная библиография. Теория моды. Одежда. Тело. Культура. 2008. Вып. 8. С. 37-60.

${ }^{27}$ Бертон Э. Филипп Арьес. Иконографические и материальные свидетельства истории семьи и детства // “Вся история наполнена детством”. С. 75-107.

${ }^{28}$ Cunningham H. Histories of Childhood. P. 1202-1204. 
there the author studied the evolution of materialistic culture of an American childhood in the course of 1600-1900 years. A set of a child's stuff (toys, furniture, clothes, plates and dishes etc. ) and their usage were changed, thus due to these changes four periods of attitude towards a child were distinguished $^{29}$. Calvert's work can serve as an illustrative example of extensive difficulties in structuring of voluminous historiography of childhood after Ariès' epoch. At a glance this work could be placed among "new (cultural) history of stuff" however stuff here is of a second-order and serves as an instrument but not as a purpose. It's well seen from the introduction where the author polemized with Ariès and took into account his research questions raised in the issue.

In general the development of suchlike explorations after Ariès' epoch isn't caused by "research know-how" and new theories. As Anthony Burton thought, deep cataloguing of artefacts and their accumulation in specialized museums, the organization of thematic exhibition make the development of explorations possible ${ }^{30}$. He gives (as an example) the collections of materials originated in $17^{\text {th }}-18^{\text {th }}$ centuries from the Museum of childhood in London ${ }^{31}$. Ukrainian museums haven't got such systematic collections from the premodernism era. The only exception is an illustrative catalogue "Children and kiddies: the image of a child in an imitative arts in $17^{\text {th }}-20^{\text {th }}$ centuries". This edition containing compositions represented at a special exhibition is dedicated to collections of Lviv National Art Gallery and Lviv Sheptitsky National Museum. The above mentioned book is valuable for its illustrations. However it contains the work material from only one Ukrainian region ${ }^{32}$. Unfortunately we haven't got any special catalogues of monuments and pictures which could accumulate the necessary data from various museums across the country. Probably the most suitable and successful suchlike project is a great colorful, thematically structured catalogue of "childish" portrayals which was represented in collections of museums in Poland. The compilers systematically classified pictures according to certain categories (a child in family, education, life's hardships etc.), provided a professional review for each picture and wrote four introductory articles about different aspects of childhood in the history of Poland. Every picture is followed by a bulky

${ }^{29}$ Я використовую російський переклад книжки: Калверт К. Дети в доме: материальная культура раннего детства, 1600-1900. М., 2009.

${ }^{30}$ Бертон Э. Филипп Арьес. С. 77.

${ }^{31}$ V\&A Museum of Childhood - філія Музею Вікторії та Альберта - всесвітньо відомого британського музею декоративно-прикладного мистецтва, має чудові колекції дитячих іграшок, меблів, одягу, починаючи з XVI ст. Див. сайт музею: https://goo.gl/13 YgHd.

${ }^{32}$ Маю на увазі зображення XVII - XVIII ст. українського походження. Див.: Діти і дітлахи: образ дитини в мистецтві XVII - XX ст. Львів, 2014. 
reference of the object in turn making the historian's job easier and giving explanations $^{33}$. The book with grand illustrations "Children's routine described with a word and an image" written by outstanding Polish researchers of children's history Dorota Żołądź-Strzelczyk and Katarzyna Kabacińska-Łuczak might be served as an example of practical realization of an informational potential for analogous compilations. In the book a materialicstic world of childhood in the Polish-Lithuanian Commonwealth is explained by authors with the help of a plentiful iconography. I didn't meet a fiercful criticism of this research but in my opinion it is supposed to involve a dangerous scenario due to the straightforward explanation of the sense of canonical potrayals. Ukrainian historians should be inspired by the fact that their Polish counterparts start their report with the complaints of the way the visual sources are kept and preserved in comparison with the French work materials of pre-modernism times. But even after such complaints the researchers have completed a large complex of pictures which in turn could be the source of envy of historians from the Cossack Hetmanate ${ }^{34}$. Regarding visual history Anita Shorsch's and Ingeborg Weber-Kellermann's researches are also considered classical ${ }^{35}$.

One of the most famous Philippe Ariès' opponent is a medievalist Shulamith Shahar. She had deeply analyzed medieval medical works, educational literature, moral treatises and came to the conclusion that childhood had been distinguished since the Middle Ages hence the medieval society was more advanced than the representatives of Early Modern period. Shahar stated that the attitude towards children of those days was more akin to current days than that used to be in the $18^{\text {th }}$ century. She found a lot of descriptions of different stages of childhood, proofs of emotional affection for children, acts of care ${ }^{36}$.

Even a more radical criticism of the main Ariès' conclusions we can meet reading the work "Forgotten Children" by Linda Pollock. In her book the author deeply analyzed numerous diaries considering them as an expression of parental's love, babies' presence, warm family relations. According to her views from the $16^{\text {th }}$ century till now childhood has changed a little. It means

\footnotetext{
${ }^{33}$ The Child in the Painting from the $16^{\text {th }}$ to the Late $19^{\text {th }}$ Century in the Collections of Polish Museums. The Wilanów Palace Museum, 2004.

${ }^{34}$ Żołądź-Strzelczyk D., Kabacińska-Łuczak K. Codzienność dziecięca opisana słowem i obrazem. Życie dziecka na ziemiach polskich od XVI do XVIII wieku. Warszawa, 2012.

${ }^{35}$ Shorsch A. Images of Childhood: An Illustrated Social History. New York, 1979; WeberKellermann I. Die Familie. Geschichte, Geschichten und Bilder. Frankfurt am Main, 1976; Weber-Kellermann I. Die Kindheit. Kleidung und Wohnen, Arbeit und Spiel. Eine Kulturgeschichte. Frankfurt am Main, 1979.

${ }^{36}$ Shahar S. Childhood in the Middle Ages. New York, 1990.
} 
that irrespective of different culture in all societies the attitude towards children was determined by a biological instinct which at all costs provided survival of its own offspring. The rest is the details which don't play any important role $^{37}$. Nicholas Orme wrote a little different research work "Medieval Children" where religious doctrine was the central idea. The church promoted bringing up children using a different pattern of childhood with its own focus on the culture separated from the world of adults ${ }^{38}$.

Many of Ariès' critics approved his conclusions. However they focused their attention on the fact that he had devoted his research primarily to the upper classes of society thus they tried to explore the other social classes. A perfect example is a collective compilation of John Henderson and Richard Wall's researches containing a piece of scripts about childhood among impoverished surroundings, orphans, orphanages ${ }^{39}$. The children's life in an impecunious British families was depicted in Hugo Cunningham's monography. He had been dealing with this issue since the $17^{\text {th }}$ century. The next research of the scholar was a considerably advanced one regarding the problems and their chronology. The book "The Invention of Childhood" was published in 2006. It contains the history of childhood in Great Britain for 1500 years. The author is akin to Ariès using a great variety of sources: diaries, autobiographies, pictures, photographs. It's important that Cunningham considers childhood not as a versatile tool but as a differential depending on ethnicity, residence, gender and so on. He demonstrates how the measure between childhood and becoming an adult has been altered throughout centuries, how uneven were those changes mainly due to largescale historical events (for example wars).

An ingenious example of a chronological sequel of Ariès' book is the work of a French researcher Elisabeth Badinter who showed how a motherly love in current meaning was brought about. She started her research with the information of the $17^{\text {th }}$ century the time when there was no love of this kind and she examined its birth from the end of the $18^{\text {th }}$ century. The work in some cases is an achingly contradictory issue. It could be criticized for a series of unproved facts which were targeted at convincing the readers in the rightfulness of the researcher's conclusions. For example the case when a child was cared by the nurses or brought up in a village was treated by Badinter as a motherly indifference. Although it could have been perceived as taking care of a child. In spite of it the author showed the powerful influence of the Age of Enlightenment on bringing up children with a new concept of

\footnotetext{
${ }^{37}$ Pollock L. Forgotten Children: Parent-Child Relations from 1500-1900. Cambridge, 1983.

${ }^{38}$ Orme N. Medieval Children. New Haven and London, 2001.

${ }^{39}$ Poor Women and Children in the European Past. London, 1994.
} 
motherhood and family. Such methods could also be used for the study of the similar processes in Russian Empire ${ }^{40}$.

In fact they're already being exploited and Russian Historical discipline is e productive enough in this way. I stated above that in my review I didn't have the aim of distinguishing some national historiographies . But the history of pre-modernism childhood in Russia is relevant for Ukrainian researchers with a common corpus of sources, analysis of initiatives "from the top" etc. Without going into detail I am going to recollect primarily two books devoted to theoretical-methodological analysis of studying childhood "in the past" - a well-known work of a Soviet researcher Igor Kon "A child and society" and a generalizing research of a Russian cultural historian Diana Mamichevac "Childhood is metamorphoses of cultural point of view". To my mind both editions are doing their best to show groundworks of Soviet and Russian historians of childhood opening them for the rest of the world ${ }^{41}$. Among practical groundworks which interested me in my research are the collective set of works "Underage Subjects of Great Empire"42 and Olga Kosheleva's monography where the conception of childhood in Russia from the $16^{\text {th }}$ to the $18^{\text {th }}$ centuries is examined on the basis of recollections and information from autobiography ${ }^{43}$. Natalia Pushkareva is the author of numerous well-known works about motherhood and family relationships in pre-modernism Russia. Instantly I recall her historiographic article devoted to the history of motherhood in an interpretation of Russian historians ${ }^{44}$. In general thee Russian historiography of childhood and family life evolved through anthropologisation, cultural history and historical-demographical groundworks. Childhood is considered in the context of deconstruction of patriarchal character, examination of emotions, gender and social roles, influence of the Age of Enlightenment etc.

An important benchmark for the Ukrainian historian is usually works of Polish counterparts who have firm groundworks in the history of childhood. Related practices in the Polish-Lithuanian Commonwealth societies provided a favorable background for comparison (for example data of demography), explanation of common legal field (Magdeburg rights) etc. From this point of

40 Я послуговувався польським виданням: Badinter E. Historia miłości macierzyńskiej. Warszawa, 1998.

${ }^{41}$ Кон И. Ребенок и общество (историко-этнографическая перспектива). Москва, 1988; Мамычева Д. Детство - метаморфозы культурного взгляда. Таганрог, 2013.

42 Малолетние подданные большой империи: Филипп Арьес и история детства в России (XVIII - нач. XX века). Санкт-Петербург, 2012.

43 Кошелева О. Свое детство в Древней Руси и в России эпохи Просвещения (XVI - XVIII вв.). M., 2000.

44 Пушкарева Н. Отечественные исследования по социологии, истории и этнологии материнства. Этнографическое обозрение. 2001. № 5. С. 91-101. 
view the most noticeable scripts belong to Małgorzata Delimata ${ }^{45}$ and Dorothy Zholyand-Strzelchyk ${ }^{46}$. They focused on the issue which Ariès didn't fully examined. It was about the multifactorial influence of Christianity on everything that is related to childhood. It's important to notice that nowadays Polish historians tend to do descriptive, factual researches. The themes of the researches of great compilation "Family circle in ancient times. Childhood" can prove it. The publication of such special editions and thematical issues in the research journal ${ }^{48}$ is the evidence of keen interest to the "official historiography" and its vigorous development. Unfortunately the Ukrainian Historical discipline can't make such a boast. At the same time the most significant domestic social-demographic researches are dedicated exactly to Ukrainian territories which belonged to the Polish-Lithuanian Commonwealth. It's about Irina Voronchuk's book "The population of Volhynia in the $16^{\text {th }}$ - the first half of the $17^{\text {th }}$ centuries" where in the context of comprehensive exploration of family the author turns to the key aspects of childhood first of all procreational behavior. The research except an important generalization has significant set of facts ${ }^{49}$.

As for the direct study of childhood's history at that time the general tendencies in Ukrainian humanities were analyzed in Natalia Marchenko's article. Where the author came to conclusion that the discourse relating to the knowledge is concentrated mostly within pedagogy, psychology and partially ethnography. But the history of childhood as a historical subdiscipline is virtually absent ${ }^{50}$. It's rather important that the then well-known Ukrainian historian Volodymyr Masliychuk proclaimed a more radical position stating that the history of Ukrainian childhood doesn't exist ${ }^{51}$. At the same time Tatiana Orlova depicted the generating of childhood's history as a new branch of social history in Ukraine ${ }^{52}$. How do we get such a nonidentical assessment of historiographic situation? First of all through the ambiguous reflection of present colleagues' achievements taken from the spheres relative to History.

${ }^{45}$ Delimata M. Dziecko w Polsce średniowiecznej. Poznań, 2004.

${ }^{46}$ Żołądź-Strzelczyk D. Dziecko w dawnej Polsce. Poznań, 2006.

${ }^{47}$ W kręgu rodziny epok dawnych. Dzieciństwo. Warszawa, 2014.

48 Як приклад наведу спеціальний випуск відомого польського журналу: Acta Poloniae Historica. 1999. Vol. 79: Childhood and Youth in Historical Perspective.

49 Ворончук I. Населення Волині в XVI - першій половині XVII ст.: родина, домогосподарство, демографічні чинники. Київ, 2012.

${ }^{50}$ Марченко Н. Автобіографія дитинства у межах біографічного дискурсу. Украӥнська біографістика. 2012. Вип. 9. С. 90-109.

51 Маслійчук В. Неповнолітні злочинці в Харківському намісництві 1780-1796 pp. Харків, 2011. С. 20.

52 Орлова Т. Історія дитинства - новий напрямок соціальної історії України. Гілея: наук. вісник. 2011. Вип. 47 (№ 5). С. 138-144. 
The historians of Pedagogics have achieved more than others in studying childhood in the past. However a modern Ukrainian history of Pedagogics is a successor of the Soviet History of Pedagogics with its inclination to imitation, exceedingly ideologization, tend to be formal but not meaningful. Igor Kon paid attention to very important statistics. Thus 6774 works relating to History of Pedagogics and school system before World War I were published until 1977. Apparently most of them were dedicated to pedagogues, pedagogical institutions but there was no research devoted to a child directly ${ }^{53}$. Nowadays it has been carrying on. At the same time even when the history of teaching and upbringing in "ancient Ukraine" is meant the historians of Pedagogics writes about a happy childhood with all its fictitious elements: total education (in contemporary sense), "child-orientated" national Pedagogics and the esteemed attitude towards a child. Professional historians cite such works as examples of evident manipulations with sources, direct explanations and complete misunderstanding of historical contexts. Nevertheless historicalpedagogical researches play a key role in the general discourse, especially due to the pedagogical invasion of respective textbooks for higher educational institution $^{54}$.

Most of the available ethnographical works concerning childhood are based generally on the sources of the $19^{\text {th }}$ century. Although they are valuable for studying the History of pre-modernism times providing the consideration of "extremely continuous" phenomena appeared in $19^{\text {th }}$ century and beyond. According to my observations modern Ukrainian ethnography (ethnology) in respect of studying history of childhood in general doesn't significantly vary from the works of Marko Hrushevs'kyi, Zenon Kuzela and Nina Zaglada. Using this conclusions I don't deny the presence of important works directing towards the deconstruction of "child-orientated" myth ${ }^{55}$, studying of fundamental aspects of motherhood, playing culture etc. ${ }^{56}$ Their bibliography exceedingly

\footnotetext{
${ }^{53}$ Кон И. Ребенок и общество... С. 40.

54 Див. наприклад: Завгородня Т., Прокопів Л., Стражнікова І. Історія педагогіки: навчально-методичний посібник. Івано-Франківськ, 2014; Скільський Д. Історія української педагогіки. Ілюстрований навчальний посібник. Київ, 2012; Фіцула М. Педагогіка. Навчальний посібник для студентів вищих педагогічних закладів освіти. Київ, 2005.

55 Кись О. Материнство и детство в украинской традиции: деконструкция мифа. Социальная история. 2003: Женская и гендерная история. Москва, 2003. С. 156-172.

${ }^{56}$ Наведу кілька прикладів: Аксьонова Н. Міфо-ритуальні основи дитячих ігор (на матеріалах Слобожанщини кінця XIX -початку XX ст.): автореф. дис. ... канд. іст. наук. Київ, 2007; Боряк О. Баба-повитуха в культурно-історичній традиції українців: між профанним і сакральним. Київ, 2009; Гаврилюк Н. Картографирование явлений духовной культуры (по материалам родильной обрядности украинцев). Киев, 1981; Гаврилюк Н. Міфологічні формули на тему “походження" дітей (досвід систематизації українських текстів та інослов'янські паралелі). Мистецтвво, фольклор та етнографія слов'янських
} 
varies. Although I want to notice the general concentration on "description" and "retelling" without conceptualization within special methodology. Relevant "children's" volume of a special series "National Ukrainian culture: human lifetime" might serve as an example. "The chronologically earliest" storylines in the compilation are partially based on retelling of classics' oeuvres from the second half of the $19^{\text {th }}$ century to the beginning of the $20^{\text {th }}$ century ( for example the abovementioned Marko Hrushevs'kyi ${ }^{57}$. As for the latter the situation with the reprinting of his book already in the $21^{\text {st }}$ century is an illustrative example. The edition of 2006 is followed by illustrations and up-to-date quotes (about motherly energetic or immortal love to the child) which both are contrary to the text itself. A reprinted edition of 2017 is also deprived of an academic apparatus (except small prefaces). The absence of an informative commentary for the book is the evidence of that in a hundred years after the publication it is still considered as an "objective" source instead of just a script produced by specific authors in a specific epoch. Even more it's perceived extremely pathetic and uncritical. The author of an academic preface for the edition of 2017 writes: "The world is believed that the first ethnographer of childhood is an American researcher M. Mead [...] M.F. Hrushevs'kyi's research was published when the American researcher was an infant herself [...] Marko Hrushevs'kyi carried out an independent ingenious, fundamental, comprehensive research without professional knowledge in this sphere only possessing fragmented information about the world's progress in studying of childhood [...] it absorbed all tendencies of the global researches of childhood..."

Suchlike comparisons can prove that modern Ukrainian ethnology has many things to do in studying of a child and particularly in comprehension of Marko Hrushevs'kyi's and Zenon Kuzela's legacy. However Ukrainian historians of the earlier modernism have a more corresponding work. The bibliography of researches devoted to directly the history of childhood is paltry. One of the pioneers of this topic in terms of historical value was Volodymyr Masliychuk. Numerous pioneering researches about the age boundaries and materialistic world of childhood, juvenile delinquency, infanticides were released by him $^{59}$.

народів. ХІ Міжнародний з '̈зд славістів. Київ, 1993, С. 176-197. Щербак І. Діти в обрядах і віруваннях українців XIX - поч. XX ст. (статево-віковий аспект традиційної культури): автореф. дис. ... канд. іст. наук. Київ, 2004.

57 Народна культура українців: життєвий цикл людини. Історико-етнологічне дослідження: У 5 т. Т. 1: Діти. Дитинство. Дитяча субкультура. Київ, 2008.

58 Грушевський М., Кузеля 3. Дитина у звичаях і віруваннях українського народу. Репринт. вид. 1907 p. Київ, 2017. Ч. 2.

59 Маслійчук В. Девіантна поведінка жінки на Слобожанщині у 80-х pp. XVIII ст. (за матеріалами повітових судів Харківського намісництва). Соціум. Вип. 5. К., 2005. С. 197-215; Його ж. Про “батьківство" і “материнство” на Лівобережній Україні другої половини XVIII ст. Народна творчість та етнографія. 2008. № 5. С. 21-26; Його ж. Дитина та голодні роки (Стратегії дорослої та дитячої поведінки на Північному 
Volodymyr Masliychuk's texts are innovative because of the raised problems and they're based on deep historiographical knowledge. The author came to rather ingenious conclusions regarding the peculiarities of attitude towards the child in a patriarchal society, the influence of the Age of Enlightenment and public policy in the Cossack Hetmanate and Slobozhanshchyna. These researches are extremely essential for the further exploration of childhood in the early modernism Ukraine. The book by Elena Dziuba touches upon very important things about the child in the aspect of Cossack chiefs' way of life. The author analized a multitudinous number of letters and diaries about about their family members, especially about children, she also paid attention to the emotions' demonstration, acts of care etc. At the same time she analyzed the representatives of the elite because ordinary people were still remaining an illiterate and silent majority ${ }^{60}$. In the early modernism period in Ukraine the child was mentioned by the authors of historical-demographical practices: Elena Zamura studied the death rate of population and the attitude toward death and Yurii Voloshyn analyzed the birth rate as well ${ }^{61}$. He is the author of the research works about the principles of name given to children, infanticides and juvenile's hand working farm for children ${ }^{62}$. The latter was also analyzed by Volodymyr Masliychuk ${ }^{63}$. The issues of childhood's history have recently been studied by Anastasia Podgorna. She has published some researches dealing with the issues of anthroponimic illegitimate birth, children's diseases in Ukraine in the $18^{\text {th }}$ and $19^{\text {th }}$ centuries $^{64}$.

Лівобережжі у 80-х рр. XVIII ст.). Сіверянський літопис. 2008. № 5. С. 94-99; Його ж. Дітозгубництво на Лівобережній та Слобідській Україні у другій половині XVIII ст. Харків, 2008; Його ж. Ставлення до дітей та підлітків у другій половині XVIII ст. (Лівобережна та Слобідська Україна). Київська старовина. 2009. № 1-2. С. 64-73; Його ж. Неповнолітні злочинці в Харківському намісництві 1780-1796 pр. Харків, 2011.

${ }^{60}$ Дзюба О. Приватне життя козацької старшини XVIII ст. (на матеріалах епістолярної спадщини). Київ, 2012.

61 Замура О. "Великий шаленець": смерть і смертність в Гетьманщині XVIII ст. Київ, 2014; Волошин Ю. Розкольницькі слободи на території Північної Гетьманщини у XVIII ст. (історико-демографічний аспект). Полтава, 2005.

62 Як окремі сюжети у книгах про населення Полтави та спеціальні статті: Волошин Ю. Козаки і посполиті: Міська спільнота Полтави другої половини XVIII ст. Київ, 2016; Його ж. Servants in the Hetmanate Cities: The Case of Poltava City during the 1760-1770 s. Journal of Family History. 2017. Vol. 42. Issue 4. P. 369-380.

${ }^{63}$ Маслійчук В. До питання про дитячу та підліткову працю на Лівобережній та Слобідській Україні в другій половині XVIII ст. Повсякдення ранньомодерної України. T. I: Практики, казуси та девіації повсякдення. Київ, 2012. С. 87-98.

${ }^{64}$ Подгорна А. Ім'янаречення дітей у містечку Пирятині у 30 -х роках XIX ст. Емінак: науковий щоквартальник. 2017. № 41 (20). Т. 2. С. 23-30; Подгорна А. Позашлюбні діти в документах церковного обліку населення у XVIII - першій половині XIX століття. ЕМІНАК: науковий щоквартальник. 2019. № 3(27). С. 76-84; Подгорна А. “Дитяча чума": віспа в Свропі XVI - XVIII ст. та перші спроби боротьби з нею на Полтавщині. Сумська старовина. 2019. Вип. 54. С. 5-17. 
Ihor Serdiuk has been researching the childhood's issue in Ukraine in the early modernism period on a more deep and profound level. He is the author of several dozen of works devoted to various children's aspects: family life, a way of life, socialization, children's conception, appropriate medical knowledge, emotions ${ }^{65}$. These groundworks are generalized in some way in the special book "Little Grown Up: Child and Childhood in the $18^{\text {th }}$ century Hetmanate". The book's content is focused on the main components of childhood's lifestyle in a conventional Christian society: birth, baptism, growing and death. Among these main components are some additional subjects: midwifery, procreation and infertility, children's exploitation, marginalization and the position of children amongst other social groups. These aspects are analyzed in terms of conception, practices and demographical "realities" reflected in various sources - from religious materials to court cases and letters. Therefore an attempt was made to consolidate the history of events and the analysis of incidents while combining the method of historical demography (taking into account the discourse of natural history and reflection of "reality") with history (taking into consideration its analysis of rhetoric and concepts) ${ }^{66}$.

\section{CONCLUSIONS}

History of childhood in the early modernism epoch is poorly explored from the point of view of Ukrainian material. Lagging behind the European historiography is caused mostly by the isolation of Ukrainian historians during the Soviet period when the access to corresponding works of European counterparts was paltry. Thus the opportunity to take a look at European methodologies of children's practices couldn't be used and the important issues were left without attention. The main researches in history are not translated into Ukrainian until now. And it is one of the illustrative examples. As a result of it Ukrainian historians perceive the works through Russian historiography. Though even Russian translations of Margaret Mead's and Philippe Ariès' fundamental research works came out with a several dozen of

65 Деякі 3 них: Сердюк І. Древо без плоду: бездітність і безпліддя в суспільстві Гетьманщини. Соціум. Альманах соиіальної історії. Вип. 13-14. Київ, 2017. С. 162-181; Сердюк I. Образ дитини в судовій документації: інформаційний потенціал і пастки документальних джерел. Записки товариства імені Шевченка. T. CCLXXI: Праці Комісї̈ спеціальних (допоміжних) історичних дисциплін. Львів, 2018. С. 199-208; Сердюк И. Эмоциональная составляющая убийства "нечистого" ребенка (эпизод из жизни Гетманщины XVIII века). Антропологический форум. Санкт-Петербург, 2015. № 25. C. 118-144; Serdiuk I. Childhood and its age limits in society of Getmanat in the XVIII century. Bylye Gody. 2015. № 3. P. 499-507.

${ }^{66}$ Сердюк I. Маленький дорослий: Дитина й дитинство в Гетьманщині XVIII ст. Київ, 2018. 
years' delay. So their introduction to Ukrainian historians is viewed as a "catch-up". Another important aspect is that the early period of modernism in Ukrainian history accounts for the Cossacks epoch which is the most important component of a Ukrainian national historical myth. When in the 1990-s Ukrainian historians got an opportunity to perform free, without any ideological censorship they were set to fill the gaps in the political, economic, military history and a biographical sphere. Cossacks epoch was full of important battles, political campaigns and social changes which overshadow children's researches. While filling the main gaps from the start of the $21^{\text {st }}$ century researchers' attention was drawn also to anthropological issues, a little individual, childhood, family life of this epoch.

Today the researches of Ukrainian historians dealing with the childhood of the early modernism period are carried out primarily on the basis of combining two approaches. The first one uses the methodology of social anthropology and demography, while the second one is based on the traditions of cultural history and focuses its attention on social roles, family behavior, examining such phenomena as parenthood, death, growing up. The realization of these methodologies on chronologically and territorially different sources is considered as an important prospect of further children's practices. As to the concrete problematic cases, the deepest examination of children's stuff is needed relating to the medieval and early modernism Ukrainian religious culture - from the fundamental philosophical oeuvres to the preaching and practices of parochial clergy. The Pre-modern Ukrainian society had a religious conception of the world, church's influence on understanding such things as childhood, family life which were determinative. The research of children's materialistic world on the basis of iconography, museum monuments and archeological dig's data is considered as an important prospect. Here we can mention cataloguing, distinguishing and deep research of corresponding subjects of cultural legacy. It is believed to be effective to perform micro historical researches directing to emotions, imaginations, daily routine, deviations. The realization of these prospects would significantly improve our knowledge about the childhood in pre-modern Ukraine. For full development of childhood's history in Ukraine the institutionalization is utterly needed: specialized journals, corresponding conferences, grants, summer schools. Their function would significantly be a great contribution to further researches of the issues.

\section{SUMMARY}

Nowadays European historiography of childhood in early modernism epoch is sufficiently diverse and has a lot of groundworks. Instead of it the history of childhood in Ukraine remains to be poorly explored and it is not a 
favorable topic for historical researches. In this work the author attempted to analyze the main tendencies in the development of European children's practices and characterized the achievements of Ukrainian historians. The main conclusion was that lagging behind European historiography is caused mostly due to the isolation of Ukrainian historians in the Soviet period when the access to corresponding works of European counterparts was paltry. Thus the opportunity to take a look at European methodologies of children's practices couldn't be used and so the important issues were left without attention. The main researches in history are not translated into Ukrainian until now. As a result of it Ukrainian historians perceive them through Russian historiography with a significant delay. An early period of modernism in Ukrainian history can be accounted for the Cossacks epoch which is the most important component of the Ukrainian national historical myth which was studied primarily in the aspect of political, economic, military history and biographic data. There are solitary researches of Ukrainian historians relating to early modernism childhood which are performed on the basis of social anthropology, demography, cultural history. Correspondingly social roles, family behavior, parenthood, death and growing up are studied. The main prospect of further researches is the examination of children's stuff in medieval and early modernism Ukrainian religious culture - from the fundamental philosophical oeuvres to the preaching and practices of parochial clergy. The research of children's materialistic world on the basis of iconography, museum monuments and archeological data is a future perspective. Some institutionalization is also an urgent need for the full development of childhood's history in Ukraine.

\section{REFERENCES}

1. Аксьонова Н. Міфо-ритуальні основи дитячих ігор (на матеріалах Слобожанщини кінця XIX -початку XX ст.): автореф. дис. ... канд. іст. наук. Київ, 2007.

2. Арьес Ф. Ребенок и семейная жизнь при старом порядке. Екатеринбург, 1999.

3. Безрогов В., Кошелева О. Детство и дети: начальная библиография. Теория моды. Одежда. Тело. Культура. 2008. Вып. 8. С. 37-60.

4. Беньковскій И. Поверья и обрядности родын и крестын. Киевская старина. 1904. № 10. С. 1-3.

5. Берк П. Нові підходи до історіописання. Київ, 2010.

6. Бертон Э. Филипп Арьес. Иконографические и материальные свидетельства истории семьи и детства// "Вся история наполнена 
детством": наследие Ф. Арьеса и новые подходы к истории детства: В 4 ч. Ч. 1. Москва, 2012. С. 75-107.

7. Богдановский А. Молодые преступники: Вопрос уголовного права и уголовной политики. Санкт-Петербург, 1871.

8. Богдановский А. Развитие понятий о преступлении и наказании в русском праве до Петра Великого. Москва, 1857.

9. Боряк О. Баба-повитуха в культурно-історичній традиції українців: між профанним і сакральним. Київ, 2009.

10. Волошин Ю. Козаки і посполиті: Міська спільнота Полтави другої половини XVIII ст. Київ, 2016.

11. Волошин Ю. Розкольницькі слободи на території Північної Гетьманщини у XVIII ст. (історико-демографічний аспект). Полтава, 2005.

12. Ворончук I. Населення Волині в XVI - першій половині XVII ст.: родина, домогосподарство, демографічні чинники. Київ, 2012.

13. Гаврилюк Н. Картографирование явлений духовной культуры (по материалам родильной обрядности украинцев). Киев, 1981.

14. Гаврилюк Н. Міфологічні формули на тему “походження" дітей (досвід систематизації українських текстів та інослов’янські паралелі). Мистецтво, фольклор та етнографія слов'янських народів. ХІ Міжнародний з '̈зд славістів. Київ, 1993, С. 176-197.

15. Геннеп ван А. Обряды перехода (систематическое изучение обрядов). Москва, 1999.

16. Грушевський М., Кузеля 3. Дитина у звичаях i віруваннях українського народу. Репринт. вид. 1907 p. Київ, 2017. Ч. 2.

17. Гуревич А. Смерть как проблема исторической антропологии: о новом направлении в зарубежной историографии. Одиссей. 1989. C. $116-117$.

18. Дзюба О. Приватне життя козацької старшини XVIII ст. (на матеріалах епістолярної спадщини). Київ, 2012.

19. Дитина в звичаях і віруваннях українського народу. Матеріали 3 полудневої Київщини. Зібрав Марко Грушевський. Обробив д-р Зенон Кузеля. Матеріали до українсько-руської етнольогії. Т. VIII. Львів, 1906; Т. ІХ. Львів, 1907.

20. Діти і дітлахи: образ дитини в мистецтві XVII-XX ст. Львів, 2014.

21. Завгородня Т., Прокопів Л., Стражнікова I. Історія педагогіки: навчально-методичний посібник. Івано-Франківськ, 2014.

22. Заглада Н. Побут селянської дитини. Матеріали до монографії с. Старосілля. Київ, 1929.

23. Замура О. "Великий шаленець": смерть і смертність в Гетьманщині XVIII ст. Київ, 2014. 
24. Иванов П. Этнографические материалы, собранные в Купянском уезде Харьковской губернии. Приметы и поверья, относящиеся к беременности и к рождению детей. Этнографическое обозрение. 1897. № 1. C. 22-70.

25. Калверт К. Дети в доме: материальная культура раннего детства, 1600-1900. М., 2009.

26. Кистяковский А. Молодые преступники и учреждения для их исправления, с обозрением русских учреждений. Киев, 1878.

27. Кись О. Материнство и детство в украинской традиции: деконструкция мифа. Социальная история. 2003: Женская и гендерная история. Москва, 2003. С. 156-172.

28. Кон И. Ребенок и общество (историко-этнографическая перспектива). Москва, 1988.

29. Кошелева О. Свое детство в Древней Руси и в России эпохи Просвещения (XVI-XVIII вв.). Москва, 2000.

30. Любарт М. Историко-этнологическое изучение детства во французской науке (до и после Ф. Арьеса). "Вся история наполнена детством": наследие Ф. Арьеса и новые подходы к истории детства: В 4 ч. Ч. 1. Москва, 2012. С. 128-129.

31. Маерчик М. Анализ дискурсов в исследованиях украинской традиции добрачных ночевок молодежи (конец XIX - XXI в.). Антропологический форум. 2015. № 24. С. 110-115.

32. Маєрчик М. Ритуал i тіло. Структурно-семантичний аналіз українських обрядів родинного циклу. Київ, 2011. С. 20-37.

33. Малолетние подданные большой империи: Филипп Арьес и история детства в России (XVIII - нач. XX века). Санкт-Петербург, 2012.

34. Мамычева Д. Детство - метаморфозы культурного взгляда. Таганрог, 2013.

35. Марченко Н. Автобіографія дитинства у межах біографічного дискурсу. Украӥнська біографістика. 2012. Вип. 9. С. 90-109.

36. Маслійчук В. Девіантна поведінка жінки на Слобожанщині у 80-x pp. XVIII ст. (за матеріалами повітових судів Харківського намісництва). Соціум. Вип. 5. К., 2005. С. 197-215.

37. Маслійчук В. Про “батьківство" і "материнство” на Лівобережній Україні другої половини XVIII ст. Народна творчість та етнографія. 2008. № 5. C. 21-26.

38. Маслійчук В. Дитина та голодні роки (Стратегії дорослої та дитячої поведінки на Північному Лівобережжі у 80-х pp. XVIII ст.). Сіверянський літопис. 2008. № 5. С. 94-99.

39. Маслійчук В. До питання про дитячу та підліткову працю на Лівобережній та Слобідській Україні в другій половині XVIII ст. 
Повсякдення ранньомодерної України. Т. I: Практики, казуси та девіаиії повсякдення. Київ, 2012. С. 87-98.

40. Маслійчук В. Дітозгубництво на Лівобережній та Слобідській Україні у другій половині XVIII ст. Харків, 2008.

41. Маслійчук В. Неповнолітні злочинці в Харківському намісництві 1780-1796 рр. Харків, 2011.

42. Маслійчук В. Ставлення до дітей та підлітків у другій половині XVIII ст. (Лівобережна та Слобідська Україна). Київська старовина. 2009. № 1-2. С. 64-73.

43. Мид М. Культура и мир детства. Избранные произведения. Москва, 1988.

44. Милорадович В. Житье-бытье лубенского крестьянина. Українці: народні вірування, повір'я, демонологія. Київ, 1992. С. 170-341.

45. Народна культура українців: життєвий цикл людини. Історикоетнологічне дослідження: У 5 т. Т. 1: Діти. Дитинство. Дитяча субкультура. Київ, 2008.

46. Онищук А. 3 народнього життя гуцулів. I. Родини і хрестини та дитина до шестого року життя. Матеріяли до української етнольогії. Т. XV. Львів, 1912. С. 90-113.

47. Орлова T. Історія дитинства - новий напрямок соціальної історії України. Гілея: наук. вісник. 2011. Вип. 47 (№ 5). С. 138-144.

48. Подгорна А. “Дитяча чума": віспа в Свропі XVI - XVIII ст. та перші спроби боротьби з нею на Полтавщині. Сумська старовина. 2019. Вип. 54. С. 5-17.

49. Подгорна А. Ім'янаречення дітей у містечку Пирятині у 30-х роках XIX ст. Емінак: науковий щоквартальник. 2017. № 41 (20). T. 2. C. 23-30.

50. Подгорна А. Позашлюбні діти в документах церковного обліку населення у XVIII - першій половині XIX століття. ЕМIНАК: науковий щоквартальник. 2019. № 3 (27). С. 76-84.

51. Пушкарева Н. Отечественные исследования по социологии, истории и этнологии материнства. Этнографическое обозрение. 2001. № 5. С. 91-101

52. Сердюк И. Эмоциональная составляющая убийства "нечистого" ребенка (эпизод из жизни Гетманщины XVIII века). Антропологический форум. Санкт-Петербург, 2015. № 25. С. 118-144.

53. Сердюк І. Древо без плоду: бездітність і безпліддя в суспільстві Гетьманщини. Соиіум. Альманах соиіальної історії. Вип. 13-14. Київ, 2017. C. $162-181$.

54. Сердюк I. Маленький дорослий: Дитина й дитинство в Гетьманщині XVIII ст. Київ, 2018. 
55. Сердюк I. Образ дитини в судовій документації: інформаційний потенціал і пастки документальних джерел. Записки товариства імені Шевченка. T. CCLXXI: Праці Комісії спеціальних (допоміжних) історичних дисииплін. Львів, 2018. С. 199-208.

56. Скільський Д. Історія української педагогіки. Ілюстрований навчальний посібник. Київ, 2012.

57. Сумцов Н. О славянских народных воззрениях на новорожденного ребенка. Журнал Министерства народнаго просвещения. 1880. № 11. C. 69-94.

58. Талько-Грынцевич Ю. Народное акушерство в Южной Руси. Чернигов, 1889.

59. Фіцула М. Педагогіка. Навчальний посібник для студентів вищих педагогічних закладів освіти. Київ, 2005.

60. Шекерик-Доників П. Родини і хрестини на Гуцульщині (В селі Головах і Красноілі Косівського пов.). Матеріяли до украӥнської етнольогії. Т. XVIII. Львів, 1918. С. 36-122.

61. Щербак I. Діти в обрядах і віруваннях українців XIX - поч. XX ст. (статево-віковий аспект традиційної культури): автореф. дис. ... канд. іст. наук. Київ, 2004.

62. Ariès P. Centuries of Childhood. A Social History of Family Life. New York, 1962.

63. Ariès P. L'enfant et la vie familiale sous l'Ancien régime. Paris, 1960.

64. Badinter E. Historia miłości macierzyńskiej. Warszawa, 1998.

65. Bowman V. Scholarly Resources for Children and Childhood Studies: A Research Guide and Annotated Bibliography. Toronto, 2007.

66. Cunningham H. Histories of Childhood. The American Historical Review. 1998. Vol. 103. Issue 4. P. 1195-1196.

67. Cunningham H. The Children of the Poor: Representations of Childhood since the Seventeenth Century. Cambridge, 1992.

68. Cunningham H. The Invention of Childhood. London, 2006.

69. Delimata M. Dziecko w Polsce średniowiecznej. Poznań, 2004.

70. DeMause L. (1982). Foundations of psychohistory. New York, 1982.

71. DeMause L. The History of Childhood: The Untold Story of Child Abuse. Northvale, New Jersey, 1995.

72. Freeman D. Margaret Mead and Samoa: The Making and Unmaking of an Anthropological Myth. Cambridge, 1983.

73. Malthus, Medicine \& Morality: "Malthusianism" After 1798. Amsterdam; Atlanta, 2000.

74. Mead M. Coming of Age in Samoa: A Psychological Study of Primitive Youth for Western Civilization. New York, 1928.

75. Orme N. Medieval Children. New Haven and London, 2001. 
76. Pollock L. Forgotten Children: Parent-Child Relations from 1500-1900. Cambridge, 1983.

77. Poor Women and Children in the European Past. London, 1994.

78. Serdiuk I. Childhood and its age limits in society of Getmanat in the XVIII century. Bylye Gody. 2015. №3. P. 499-507.

79. Shahar S. Childhood in the Middle Ages. New York, 1990.

80. Shorsch A. Images of Childhood: An Illustrated Social History. New York, 1979.

81. The Child in the Painting from the $16^{\text {th }}$ to the Late $19^{\text {th }}$ Century in the Collections of Polish Museums. The Wilanów Palace Museum, 2004.

82. Voloshyn Ju. Servants in the Hetmanate Cities: The Case of Poltava City during the 1760-1770 s. Journal of Family History. 2017. Vol. 42. Issue 4. P. 369-380.

83. W kręgu rodziny epok dawnych. Dzieciństwo. Warszawa, 2014.

84. Weber-Kellermann I. Die Familie. Geschichte, Geschichten und Bilder. Frankfurt am Main, 1976.

85. Weber-Kellermann I. Die Kindheit. Kleidung und Wohnen, Arbeit und Spiel. Eine Kulturgeschichte. Frankfurt am Main, 1979.

86. Żołądź-Strzelczyk D. Dziecko w dawnej Polsce. Poznań, 2006.

87. Żołądź-Strzelczyk D., Kabacińska-Łuczak K. Codzienność dziecięca opisana słowem i obrazem. Życie dziecka na ziemiach polskich od XVI do XVIII wieku. Warszawa, 2012.

Information about the author: Serdiuk I. O.,

Doctor of History, Professor at the Department of History of Ukraine, Poltava V.G. Korolenko National Pedagogical University

2, Ostrohradskyi str., Poltava, 36003, Ukraine 